Aguilar-Luzón, M. C., Calvo-Salguero, A. \& Salinas, J. M. (2014). Beliefs and environmental behavior: The moderating effect of emotional intelligence. Scandinavian Journal of Psychology 55, 619-629. DOI: 10.1111/sjop.12160

\title{
Beliefs and environmental behavior: The moderating effect of Emotional Intelligence
}

MARIA CARMEN AGUILAR-LUZÓN,

ANTONIA CALVO-SALGUERO and

JOSÉ MARIA SALINAS

University of Granada, Granada, Spain

Recent decades have seen a proliferation of studies aiming to explain how proenvironmental behavior is shaped by attitudes, values and beliefs. In this study, we have included an aspect in our analysis that has been rarely touched upon until now, that is, the intelligent use of emotions as a possible component of pro-environmental behavior. We applied the Trait Meta Mood Scale-24 (TMMS-24) and the New Environmental Paradigm scale to a sample of 184 male and female undergraduate students. We also carried out correlation and hierarchical regression analyses of blocks. The results show the interaction effects of the system of environmental beliefs and the dimensions of emotional intelligence on glass recycling attitudes, intentions and behavior. The results are discussed from the perspective of research on how the management of emotions guides thought and behavior.

Key words: Ecocentrism, anthropocentrism, emotional intelligence, New Environmental Paradigm, pro-environmental behavior.

Maria Carmen Aguilar-Luzón, Social Psychology, University of Granada, Campus

Cartuja, s/n. 18071, Granada, Spain. E-mail: maguilarluzon@ugr.es 


\section{INTRODUCTION}

Recent decades have seen a proliferation of studies carried out from a psychosocial perspective aiming to explain different aspects of environmental awareness and proenvironmental behavior. A significant number of these studies have analyzed proenvironmental behavior stemming from attitudes, values and beliefs (Aguilar-Luzón, García, Calvo-Salguero \& Salinas, 2012; Aragonés \& Amérigo, 1991; Bamberg \& Møser, 2007; Berenguer, 2000; Bolzan de Campos \& Pol, 2010; Corraliza \& Martın, 2000; Garcia-Mira \& Real-Deus, 2001; Stern, 1992). Despite the fact that these studies represent a major advance in understanding and predicting pro-environmental behavior, their findings raise doubts about whether the factors, which we have been analyzing, actually lead to behaviors aimed at protecting and conserving the environment. Thus, while some authors have observed a high level of environmental concern among the popu- lation at large (e.g., Bolzan de Campos, 2008; Berenguer, Corraliza, Martín \& Oceja, 2001; Corraliza, Berenguer, Mu^oz \& Martín, 1995; González, 2004; Gooch, 1995), others have found low correlations between these attitudes and engagement in pro-environmental behavior (Aragonés, 1990; Dunlap, 1991; Iniguez, 1994; Scott \& Willits, 1994).

There is an ongoing debate as to the dimensions of the environmental belief system driving sustainable behavior. For some, environmental beliefs have a two-dimensional structure, that is, Ecocentrism vs. Anthropocentrism (Amérigo, Aragonés, Sevillano \& Cortés 2005; Dreger \& Chandler, 1993; García-Mira, Santos, Gómez-Durán, Romay \& Fernández, 1998; Vozmediano \& San Juan, 2005), yet there are studies, subsequently confirmed by other authors, (Amérigo, Aragonés, De Frutos, Sevillano \& Cortés, 2007; Schultz, 2000, 2001; Snelgar, 2006), which empir- ically support the existence of a tripartite structure of beliefs (egoistic, altruistic and biospheric) about the consequences of environmental degradation. Palavecinos, Amérigo and Munoz (2010) recently described four dimensions for these beliefs: egoistic, socio-altruistic, biospheric and egobiocentric. It should be pointed out that the scale that was developed under the New Environmental Paradigm (NEP) and which is frequently used to measure environmental beliefs (Bragg, 1996), appears to behave differently depending on the nationality of the sample. In sam- ples from the United States, the ecocentrism factor appears as diametrically opposed to human exceptionalism, namely, anthropocentrism; however, in Latin American or Japanese samples, a significant, positive covariance exists between ecocentrism and anthropocentrism (Bechtel, Corral-Verdugo, Asai 
\& González, 2006; Bechtel, Corral-Verdugo \& Pinheiro, 1999; Corral- Verdugo \& Armendáriz, 2000). Whenever the NEP is applied to Spanish samples, results reveal that anthropocentrism is negatively related to pro-environmental behavior (e.g., Amérigo \& González, 1999; González \& Amérigo, 1999; Vozmediano \& San Juan, 2005). Accordingly, these results would seem to indi- cate that the NEP scale is subject to the peculiarities of the sample used (Hawcroft \& Milfont, 2010), which might explain the heterogeneity of results. This inconsistency of results would lead us to question whether the attitude-environmental behavior gap might be due to other intervening factors or variables, as yet unidentified in the literature. In the case of behavior, it would be important to identify these factors and to determine the relation- ship between them, in order to enhance the explanation, prediction and intervention of pro-environmental behavior (Schmuck \& Schultz, 2002; Vozmediano \& San Juan, 2005). Consequently, we believe that identification of variables that will facilitate pre- diction of pro-environmental behavior should become a priority research objective (Garcia-Mira \& Real-Deus, 2001).

Currently, the regulation and management of emotions has become a research topic of great interest. In relation to this issue, and taking into account the emotions that are evoked by and involved in environmental causes, we believe that pro-environ- mental behavior is determined not only by cognitive factors but also by human emotivity. Thus, environmental representation processes become highly relevant in explaining proenvironmental behavior, which depends not only on the perception and knowledge of environmental conditions, but also on the emotional activity associated with these conditions (Syme, Beven \& Sumner, 1993). Kals, Schumacher and Montada (1999) reached similar conclusions, claiming that emotional motivation is the best predictor of environmental behavior. According to Hartig, Kaiser and Bowler (2001), positive emotions are more closely related to pro-environmental behavior. Grob (1995), however, states that negative emotional reactions evoked by environmental degradation will foster engagement in pro-environmental behavior. In this respect, some studies have found that certain emotions, such as anger, contribute to explaining pro-environmental behavior and are even more important than one of the major elements of the Theory of Planned Behavior - TPB (Ajzen, 1991), namely, perceived behavioral control (Durán, Alzate, López \& Sabucedo, 2007). Similarly, other authors report that the capacity of the TPB elements to predict behavior is increased when the effects of identification with Nature are taken into account, along with affective and emotional factors associated with the environment (Hinds, 2006; 
Stets \& Biga, 2003). Thus, environmental behavior is closely related to emotion (Carrus, Passafaro \& Bonnes, 2008). These results suggest that failure to consider affectivity as a generating factor of pro-environmental behavior may hamper the development of scientific theory and knowledge in this field of study. Frith and Singer (2008) state that decisionmaking depends on the capacity of an individual to understand beliefs and emotions; accordingly, the interaction between emotion and cognition acquires a fundamental role in the study of human behavior. Goleman (2009) describes the ability of people to perceive the connection between human activities and their impact on the environment, by defining a new construct: ecological intelligence. Goleman believes that it is a question of people's ability to adapt to their ecological niche, making it possible to apply what we have learned about how human activity impinges on the ecosystems, so as to "do less harm and once again to live sustainably on our planet" (Goleman, 2009, p. 51).

Although analysis of the interaction between emotions, cognition and behavior is not new, the "emotional intelligence" construct has generated significant interest in a growing area of research. Consequently, different theoretical models (Bar-On, 2000; Goleman, 1995; Mayer \& Salovey, 1997; Salovey \& Mayer, 1990) have been developed. Among these, the model pro- posed by Salovey and Mayer (1990) has generated a substantial number of investigations within the scientific community. One of the first formal definitions of this construct was given by Mayer, Salovey, Caruso and Sitarenios (2001, p. 239), who defined it as: "a part of social intelligence that includes the ability to control one's own and others' feelings, to discriminate among them and to use this information to guide our thinking and actions."

Existing studies highlight the importance of its role in predicting a wide range of behaviors in very diverse contexts, such as education, health, work, family and interpersonal relationships, etc. (e.g., Abdullah, Elias, Mahyuddin \& Uli, 2004; Lopes, Cotè \& Salovey, 2007; Otto \& Lanterman, 2006; Salovey \& Mayer, 1990; Tsaousis \& Nikolaou, 2005;). Ciarrochi, Forgas and Mayer (2001) proposed an interesting hypothetical model to explain how emotional intelligence can mediate the impact of everyday events. The premise of the model is that emotional intelligence has an impact on the way in which we perceive important life events and everyday occurrences, and hence on the degree to which we adapt to our environment, thereby deter- mining our responses and consequently affecting life outcomes such as physical and mental health status, success at school or work, or the quality of social relationships. Generally speaking, findings suggest that emotionally intelligent 
people show more adaptive responses to their environment, whereas people with lower levels of emotional intelligence do not adapt so well and their responses lead to negative life outcomes (Augusto-Landa, López-Zafra, Berrios-Martos \& Aguilar-Luzón, 2008). These findings are understandable, particularly if we bear in mind that emotions, as well as cognitive aspects (e.g., beliefs, attitudes and values) are the basic pillars of behavior. The interaction of these two factors plays an important role in any human learning pro- cess, determining action and behavior.

Since Mayer and Salovey's model (1997), different measures of emotional intelligence have been developed. These can be classified into two different types: self-report versus ability measures. Both types of measures have advantages and disadvantages.

On the one hand, self-report measures are usually better predictors than ability measures. One plausible explanation for this is that self-report measures show significant correlations with personality variables (Bracket \& Salovey, 2006). However, a different explanation could be that the measuring method is shared with criteria variables such as anxiety or depression, which are also evaluated using self-reports (Extremera \& Fernández- Berrocal, 2004). Recent research, however, suggests that self- reports of emotional intelligence correlate with other measures that are not self-reported (Lumley, Gustavson, Partridge \& Labouvie-Vief, 2005) and therefore, the shared variance is only due to the shared method. Similarly, various studies highlight the incremental validity of self-report measures for emotional intelligence. One of these is the TMMS, predicting the variance of different criteria variables (happiness, satisfaction with life, loneliness, depression and anxiety) independently from personal- it variables (Extremera \& Fernández-Berrocal, 2005). Selfreport measures provide information about experiences and internal beliefs, and evaluate consciousness processes related to emotional thinking. These variables would be more difficult to obtain with realization measures, whereas self-report measures are faster to complete, easy to use (only brief instructions are necessary), and can be obtained either collectively or privately (Extremera \& Fernández-Berrocal, 2004).

On the other hand, ability measures have been shown to have strong links with age, verbal intelligence or educational level (Goldenberg, Matheson \& Mantler, 2006). These measures are context-related and need to be adapted, depending on the population evaluated (Brackett \& Salovey, 2006). Detailed instructions are needed to execute each of its tasks, and take longer to be completed in comparison with self-report measures. The 
time required for the completion of ability measures could increase the risk of bias due to tiredness. Indeed, some authors have questioned the capacity of these tests to evaluate emotional intelligence ability, arguing that these evaluate the knowledge of the emotional strategies that are effective in managing different situations, but not the ability to implement these strategies in daily life (Lopes et al., 2007). The correction of scoring methods such as the agreement method or the expert judgement method have been criticized, given that they could reflect a social conformity response rather than an emotionally intelligent response (Roberts, Zeidner \& Matthews, 2001). In addition, a high invest- ment is needed to obtain the test and to subsequently standardize scores from the subjects, whereas self-report measures are free, requiring only a piece of paper and a pencil.

We can conclude that the validity of each measure is dependent on the objectives or the aim of the study (Furnham, Chamorro- Premuzic \& Moutafi, 2005). Recent research (Lumley et al., 2005) has shown how a three-factor model lies behind the factorial analysis both with self-report and ability measures. This confirms the belief that we are measuring the same concept (emotional abilities) from different perspectives (belief and reality).

To carry out this research study we have focused on the Mayer and Salovey Model (1997), and in particular on the self- report measure of intrapersonal emotional intelligence, TMMS24 (Spanish version; Fernández-Berrocal, Extremera \& Ramos, 2004). Our choice is based on the validated psychometric properties, the time that it requires to be completed (thus avoiding the tiredness of the participants caused by completing different scales and questionnaires), the easy instructions, and the low budget that it requires.

In the analysis of environmental behavior, a person's ability to identify and manage processed emotional information, that is, intelligent management of the emotions that may arise in a given situation, is just as important as the actual emotion invoked. In other words, this construct of emotional intelligence brings together two interesting fields of study: affect processes and cognition, which, until relatively recently, were considered to be separable and often opposing processes (Mayer, 2001). Certain situations may invoke the same emotion in different people; however, each person will acknowledge, understand, interpret and repair that same emotion in a different way and change their behavioral reaction accordingly. Thus, it would seem logical to propose that intelligent management of emotions may also play an essential part in the process of adopting values, beliefs, attitudes and pro-environmental 
behavior, and in fostering engagement in positive behavior, thereby enhancing environmental conservation.

In spite of the logic of this proposal, there are, to our knowledge, no empirical studies that have examined the role of emotional intelligence in predicting pro-environmental behavior. An extensive review of the literature to date has failed to find any studies relating to this specific issue. Therefore, we believe that it would be worthwhile to determine whether an intelligent use of emotions is related to pro-environmental behavior, and whether this may help explain behavior and foster actions aimed at environmental conservation.

\section{THIS STUDY}

Within the frame of reference described above, the objective of this study is to analyze the possible role of emotional intelligence as a moderator variable in the relationship between anthropocentric beliefs, ecocentric beliefs, and pro-environmental behavior. Given that no prior studies have examined the relation- ship between emotional intelligence, environmental beliefs and pro-environmental behavior, this study will introduce a possible theoretical approach that may explain the relations between the dimensions of emotional intelligence, anthropocentric and eco- centric beliefs, and pro-environmental behavior.

Existing literature has shown that there are two systems of social-environmental beliefs: the first is defined in the "Dominant Social Paradigm" and is characterized by anthropocentrism; the second is defined in the "New Ecological Paradigm" and is characterized by ecocentrism (Amérigo, 2009; Amérigo et al., 2007; Dunlap, Van Liere, Merting \& Jones, 2000; Vozmediano \& San Juan, 2005). Anthropocentrism identifies with ideas of productivity, progress and unlimited human exceptionalism. This dimension means valuing the natural environment for its contribution to the quality of human life. Ecocentrism means becoming aware that human intervention can disturb the natural equilibrium, limiting the growth of human societies and questioning the right of human beings to rule over Nature. This dimension means valuing Nature itself, that is, believing that it has an intrinsic value and that human beings are just another element therein. In this regard, some studies have suggested that stronger ecocentric beliefs should imply a higher level of engagement in environ- mental behavior, and similarly, that stronger anthropocentric beliefs would mean less engagement (González \& Amérigo, 1999; Pato, Ros \& Tamayo, 2005; Vozmediano \& San Juan, 2005). We should analyze whether a high 
level of ecocentric beliefs and an appropriate level of emotional intelligence serve to enhance attitude, intention to recycle and actual behavior. This study specifically examines whether emotional intelligence acts as a moderator variable between the system of environmental beliefs, attitudes towards glass recycling, behavioral intention and behavior. Studies suggest that stronger ecocentric beliefs should imply a higher level of engagement in environmental behavior and similarly, that stronger anthropocentric beliefs would imply a lower level. According to Schultz, Shriver, Tabanico and Khazian (2004), environmental concern (ecocentric and anthropocentric beliefs) involves emotional components that could motivate pro-environmental behavior. If emotional intelligence represents a capacity to regulate, namely, to direct and channel, our emotions and to discern such emotions and use the information to guide our thoughts and behavior, we should then consider its potential moderating role between environmental beliefs and pro-environmental attitudes and behavior. Generally speaking, people holding stronger ecocentric or pro-environmental beliefs are more concerned about the environment. In relation to the ideas presented by Schultz et al. (2004), the emotional components in these beliefs are the motivational factor that triggers the pro-environmental behavior. However, this would only be true if the person knows or shows a high ability to distinguish or identify the emotions triggered as well as being able to regulate them correctly, that is, if the person shows high emotional intelligence. Following the definition of this construct, people who show this ability display attitudes, intentions and behaviors according to their beliefs and values. In contrast if the person shows low emotional intelligence although showing high attachment to ecocentric beliefs, the probability of that person exhibiting attitudes, intentions and behaviors according to his or her beliefs will be lower, due to their lack of ability to regulate the emotions that are the motivating factor for the behavior. Thus, a person with strong ecocentric beliefs can see a forest burning or an image of the destruction of nature, which will possibly generate emotions related to his or her environmental beliefs. However, if this person is not able to identify these emotions and regulate them, she or he will not produce behavior according to his or her beliefs. In addition, if a person is capable of identifying the emotions that they are feeling and able to regulate them, they would be expected to exhibit behavior according to his or her environmental beliefs. Therefore, people with strong ecocentric beliefs and an appropriate level of emotional intelligence, would be expected to have a more favorable attitude to recycling, a firmer intention to recycle, and to engage more frequently in recycling behavior. Their capacity to appropriately direct and channel the feelings invoked by their beliefs will affect their 
attitudes, their behavioral disposition and actual behavior, making them consistent with their beliefs. Accordingly, the following hypotheses were set:

Hypothesis 1 (H.1). Emotional intelligence acts as a moderator variable between ecocentric beliefs and attitude, intention and pro-environmental behavior. Participants who have stronger ecocentric beliefs and who are more skilled in assessing and regulating their emotions, will show a more favorable attitude towards behavior (H.1.a), a greater intention to engage in such behavior (H.1.b) and will engage more frequently in pro-environmental behavior (H.1.c).

This may be due to the fact that, generally speaking, people who hold strong ecocentric or pro-environmental beliefs, feel concern for the environment. Accordingly, they will probably have intense emotional reactions to adverse or negative environ- mental situations. The ability to favorably manage these emotions may consequently affect the frequency of pro-environmental behavior.

In contrast, people who hold strong anthropocentric or anti-environmental beliefs generally feel less concerned about environmental conservation. Therefore, these people will have a less favorable attitude to behavior, less intention to behave accordingly, and less frequent pro-environmental behavior.

Following the rationale of Schultz et al.'s (2004), anthropocentric beliefs raise emotions that do not motivate pro-environ- mental behavior. Therefore, having high emotional intelligence, which allows for the identification and regulation of these emotions, should not provoke the attitudes, intentions and behaviors that are favorable for the environment. That is, a person that presents a high attachment to anthropocentric beliefs, can see a burning forest or an image of nature in a state of destruction, and not generate driving or motivating emotions for pro-environ- mental behavior. Thus, not presenting these emotions due to high emotional intelligence will not change their behavior.

Therefore, people holding strong anthropocentric beliefs and an appropriate level of emotional intelligence, would be expected to have a less favorable attitude to recycling, less intention to recycle and less frequent recycling behavior because their skills at directing and channelling the emotions invoked by their beliefs will affect their attitudes, behavioral disposition and actual behavior, making them consistent with their beliefs. 
Thus, the following hypotheses were set:

Hypothesis 2 (H.2). Emotional intelligence acts as a moderating variable between anthropocentric beliefs and pro- environmental attitude, intention and behavior. Participants holding stronger anthropocentric beliefs and better skills to respond to and regulate their emotions, will have a less favorable attitude to behavior (H.2.a), less intention to behave accordingly (H.2.b) and less frequent pro-environ- mental behavior (H.2.c).

\section{METHODOLOGY}

\section{Participants and procedure}

To carry out this study, we used a sample of 184 male (46) and female (138) undergraduates enrolled in the Degree in Social Education program at Granada University (Spain); average age 21.55 years (SD: 5.32). Participation was voluntary and questionnaires were anonymous. Two hundred one questionnaires were applied in the classroom; 18 incomplete or incorrectly completed questionnaires were discarded. The response rate was $91.5 \%$.

\section{Variables and measuring instruments}

Emotional intelligence was evaluated using the Trait Meta-Mood Scale (TMMS-24; Salovey, Mayer, Goldman, Turvey \& Palfai, 1995), adapted to the Spanish context by Fernández-Berrocal, Extremera and Ramos (2004). This scale uses 24 items for the evaluation and includes three factors for perceived emotional intelligence: attention to feelings; emotional clarity; and emotional repair. Emotional attention refers to the degree to which a person tends to observe and identify their feelings and emotions (8 items: e.g., "I think about my mood constantly"). Emotional clarity refers to the tendency of an individual to understand their own feelings and emotions (8 items: e.g., "I am frequently con- fused about how I feel"). Emotional repair refers to a person's tendency to regulate their own feelings and emotions (8 items: e.g., "Although I am sometimes sad, I have a mostly optimistic outlook"). A Likert-type scale was used to measure responses, with response options ranging from 1 to 5. Cronbach's alpha coefficients, as obtained by Fernández-Berrocal et al. (2004), were as follows: Attention factor: 0.86; Clarity factor: 0.90; and Repair: 0.86. In this study, the following Cronbach's alpha coefficients were 
obtained: Attention:0 .88; Clarity: 0.87, and Repair: 0.82.

The aggregate score obtained from this questionnaire has been used in some studies in which the TMMS was applied to analyze the relationship between emotional intelligence and different constructs (e.g., Fullam, 2002; Kim, 2005; Kokkarinen \& Cotgrave, 2010). However, we did not think it advisable to ana- lyze the data using an aggregate score for emotional intelligence, as the TMMS was not designed with this purpose in mind (PerezGonzález, Petrides \& Furnham, 2005). It is worth noting that a high or low score on the TMMS in the dimension of emotional attention is assumed to be insufficient. Thus a high score in emotional attention cannot be interpreted as an indicator of greater emotional intelligence.

Environmental beliefs were evaluated using the New Environ- mental Paradigm scale (NEP; Dunlap et al., 2000), which was adapted to Spanish samples by Vozmediano and San Juan (2005). The Spanish version has 11 items, grouped into two sub-scales: anthropocentrism (e.g., "Humans have the right to modify the natural environment to suit their needs") and eco- centrism (e.g., "Plants and animals have as much right as humans to exist"). A Likert-type scale was used, with seven response options. Cronbach's alpha values, as obtained by Vozmediano and San Juan (2005), were: Anthropocentrism: 0.71; Ecocentrism: 0.71. The following Cronbach's alpha values were obtained in this study: Anthropocentrism: 0.77 and Eco- centrism: 0.70 .

The dependent variables included attitude towards behavior, and behavioral intention and frequency of behavior - in our case, "separating glass from other waste for recycling." Attitude towards behavior refers to where a person is located or positioned on a bipolar, evaluative dimension with respect to the behavior under study (Fishbein \& Ajzen, 1975). The following item was used as a direct measure to quantify this variable: "What would your attitude be about separating glass from other waste for recycling over the next twenty days?" A Likert-type, seven-point response scale was used, with response options rang- ing from $(-3)$ "totally unfavorable" to $(+3)$ "totally favorable." Behavioral intention was also measured directly by a single item: "Over the next 20 days, I will separate glass from other waste for recycling." A seven-point unipolar scale was used, with response options ranging from (1) "highly unlikely" to (7) "highly likely." Pro-environmental behavior, namely, separating glass from other waste, was evaluated by asking respondents how frequently they separated glass from other waste for recycling. The measurement scale offered four response 
options: never; hardly ever; sometimes; and usually.

\section{RESULTS}

The SPSS 17.0 statistics package was used to analyze the data. We first calculated the correlations between all variables included in the study: age; gender; beliefs evaluated using the NEP scale (anthropocentrism and ecocentrism); the three factors of emotional intelligence (attention, clarity and repair); and attitude towards the behavior, behavioral intention and glass recycling behavior. The correlation matrix is shown in Table 1. Significant correlations included a positive correlation between ecocentrism and attention, emotional repair, attitude towards behavior, behavioral intention and behavior; a positive correlation between anthropocentrism and emotional clarity; and a negative correlation between anthropocentrism and behavioral intention and pro-environmental behavior. Ecocentrism and anthropocentrism correlated negatively.

Hierarchical regression analyses by blocks were carried out in order to prove the predictive capacity of the three dimensions of emotional intelligence vis-à-vis anthropocentric and ecocentric beliefs. In order to overcome the problem of possible collinearity between the interactions of the variables, the standardized scores ( $\mathrm{Z}$ scores) for each variable were used, as recommended by Aiken and West (1992). In addition, to test if there were some collinearity problems between the variables in the study, we performed a multi-collinearity analysis. To analyze the possible multi-collinearity, we calculated the Variance Inflation Factor (VIF) and the tolerance of all the components of the regression equations. The results show an absence of multi-collinearity between the variables. The maximum index of multi-collinearity is obtained for the interaction between NEP and the reparation, VIF $=1.875$, tolerance $=0.533$ that do not reach the critical values usually considered VIF > 10, o tolerance < 0.1 (Belsley, 1982; Belsley, Kuh \& Welsch, 1980). In general, the condition number K 8x) = 3.1 is below the critical value 20 (Belsley, 1982; Belsley et al., 1980).

Three regression analyses were carried out, that is, one for each dependent variable: attitude towards behavior, behavioral intention and recycling behavior. Following Baron and Kenny (1986), in the first block, age, gender (variables control) and the two dimensions of environmental beliefs were included (anthropocentrism and ecocentrism), as predictors. In the second block, the dimensions of emotional intelligence (moderator variable) were 
included. In the third block, the interactions (predictor 9 moderator) between the dimensions of the beliefs and the dimensions of emotional intelligence were included.

Table 1. Correlations between the study variables

\begin{tabular}{|c|c|c|c|c|c|c|c|c|c|}
\hline & 1 & 2 & 3 & 4 & 5 & 6 & 7 & 8 & 9 \\
\hline 1. Gender & - & & & & & & & & \\
\hline 2. Age & -0.089 & - & & & & & & & \\
\hline 3. Ecocentrism & 0.039 & -0.006 & - & & & & & & \\
\hline 4. Anthropocentrism & $-0.215^{* *}$ & 0.020 & $-0.418 * *$ & - & & & & & \\
\hline 5. Attention & $0.166^{*}$ & -0.054 & $0.229 * *$ & 0.032 & - & & & & \\
\hline 6. Clarity & -0.106 & $0.161 *$ & -0.135 & $0.243 * *$ & $0.189^{*}$ & - & & & \\
\hline 7. Repair & 0.031 & 0.118 & $0.146^{*}$ & 0.056 & 0.098 & $0.311 * *$ & - & & \\
\hline 8. Attitude & -0.113 & 0.145 & $0.176^{*}$ & -0.129 & -0.014 & 0.039 & $0.167 *$ & - & \\
\hline 9. Intention & 0.016 & $0.206^{* *}$ & $0.193 * *$ & $-0.190 * *$ & 0.014 & 0.042 & 0.085 & $0.489^{* *}$ & - \\
\hline 10. Behavior & -0.025 & $0.163 *$ & $0.196 * *$ & $-0.195 * *$ & -0.043 & 0.070 & 0.109 & $0.474 * *$ & $0.758 * *$ \\
\hline
\end{tabular}

$* p<0.05 ; * * p<0.01$.

The results obtained for the three dependent variables (See Table 2) revealed that there were only significant effects in the third block or model tested, namely, when we looked at the effects of emotional intelligence on the system of environmental beliefs. In the case of attitude towards behavior, we observed interaction effects between ecocentric beliefs and emotional attention and similarly, between anthropocentric beliefs and emotional repair. The percentage of explained variance in the case of attitude towards behavior for the whole model was $15.3 \%$. The R2 increase in the third block, in respect of the second, was $6.2 \%$ ( $p$ $=0.058)$.

In the case of behavioral intention, the results highlighted the existence of significant interactions between ecocentric beliefs and emotional clarity and between anthropocentric beliefs and emotional repair (See Table 3). The percentage of explained var- iance in behavioral intention for the whole model (third block) was $22.4 \%$. The $\mathrm{R} 2$ increase in the third block, with respect to the second, was $12.3 \%(\mathrm{p}=0.000)$.

The results for glass separating behavior revealed that there were interactions between ecocentric beliefs and emotional clarity (See Table 4). The percentage of explained variance in behavior for the whole model was $21.2 \%$. The $\mathrm{R} 2$ increase in the third block, with respect to the second was $11 \%(\mathrm{p}=0.001)$.

In order to ensure that they were interpreted correctly, we plotted the interaction effects between the system of environmental beliefs and emotional intelligence, in the case of 
recycling attitude, intention and behavior, as recommended by Aiken and West (1992). As shown in Fig. 1, when respondents showed a low degree of emotional attention, we found no effects of eco- centrism on the attitude towards the behavior. Nonetheless, as the level of emotional attention increased and stronger ecocentric beliefs emerged, the attitude towards glass recycling became more favorable.

The results obtained for behavioral intention show that there are interaction effects between emotional clarity and ecocentric beliefs. An increase in emotional clarity leads to a rise in the gradient of the line predicting behavioral intention, in keeping with the degree of ecocentrism, as shown in Fig. 2. Hence, when there is a high degree of both emotional clarity and ecocentrism, the values obtained for behavioral intention will also be high.

The findings related to glass recycling behavior revealed inter- action effects between emotional clarity and ecocentrism, as shown in Fig. 3. When ecocentrism is low, emotional clarity has no effect on behavior. Stronger ecocentric beliefs and emotional clarity, however, lead to a greater frequency of behavior.

Figure 4 shows the effects of the interaction between anthropocentric beliefs and emotional repair on the attitude towards the behavior; when anthropocentric beliefs are high, emotional repair has no effect on attitude towards the behavior; however, when the level of anthropocentrism is low, any increase in the degree of emotional repair leads to a more favorable attitude towards glass recycling.

In the case of behavioral intention, as shown in Fig. 5, when respondents show a low level of emotional repair, anthropocentrism is found to have no effect on behavioral intention; nonetheless, as the level of emotional repair rises, the level of anthropocentric beliefs decreases and behavioral intention becomes greater. 
Table 2. Hierarchical regression analysis of blocks. Dependent variable: Attitude towards behavior

\begin{tabular}{llrrl}
\hline Block & Model & Beta & \multicolumn{1}{l}{$\mathrm{t}$} & $p$ \\
\hline 1 & Gender & -0.118 & -1.611 & 0.109 \\
& Age & 0.137 & 1.891 & 0.060 \\
& Ecocentrism & 0.139 & 1.753 & 0.081 \\
Anthropocentrism & -0.093 & -1.153 & 0.250 \\
Gender & -0.122 & -1.618 & 0.107 \\
Age & 0.117 & 1.586 & 0.115 \\
Ecocentrism & 0.117 & 1.380 & 0.169 \\
Anthropocentrism & -0.112 & -1.352 & 0.178 \\
Attention & -0.026 & -0.336 & 0.737 \\
Clarity & 0.010 & 0.117 & 0.907 \\
Regulation & 0.146 & 1.879 & 0.062 \\
Gender & -0.132 & -1.756 & 0.081 \\
Age & 0.117 & 1.598 & 0.112 \\
Ecocentrism & 0.152 & 1.627 & 0.106 \\
Anthropocentrism & -0.104 & -1.263 & 0.208 \\
Attention & -0.036 & -0.466 & 0.642 \\
Clarity & 0.034 & 0.418 & 0.677 \\
Regulation & 0.150 & 1.906 & 0.058 \\
Ecocentrism X Attention & 0.168 & 2.081 & 0.039 \\
Ecocentrism X Clarity & -0.007 & -0.075 & 0.941 \\
Ecocentrism X Regulation & -0.081 & -0.836 & 0.404 \\
Anthropocentrism X Attention & 0.144 & 1.895 & 0.080 \\
Anthropocentrism X Clarity & -0.066 & -0.751 & 0.453 \\
Anthropocentrism X Regulation & -0.197 & -2.193 & 0.030 \\
& & & \\
& & &
\end{tabular}

$R^{2}=0.091$ for block $2 ; \mathrm{D} R^{2}=0.062$ for block $3 ; p=0.058$.

Table 3. Hierarchical regression analysis of blocks. Dependent variable: Intention

\begin{tabular}{llrrl}
\hline Block & Model & Beta & \multicolumn{1}{l}{$\mathrm{t}$} & $p$ \\
\hline 1 & & & \\
& Gender & 0.010 & 0.133 & 0.895 \\
& Age & 0.209 & 2.932 & 0.004 \\
& Ecocentrism & 0.137 & 1.753 & 0.081 \\
Anthropocentrism & -0.135 & -1.700 & 0.091 \\
Gender & 0.015 & 0.197 & 0.844 \\
Age & 0.195 & 2.670 & 0.008 \\
Ecocentrism & 0.139 & 1.646 & 0.101 \\
Anthropocentrism & -0.149 & -1.809 & 0.072 \\
Attention & -0.020 & -0.251 & 0.802 \\
Clarity & 0.060 & 0.746 & 0.457 \\
Regulation & 0.033 & 0.429 & 0.669 \\
Gender & -0.026 & -0.358 & 0.721 \\
Age & 0.179 & 2.555 & 0.011 \\
Ecocentrism & 0.072 & 0.801 & 0.424 \\
Anthropocentrism & -0.175 & 2.218 & 0.028 \\
Attention & -0.042 & -0.557 & 0.579 \\
Clarity & 0.086 & 1.110 & 0.269 \\
Regulation & 0.096 & 1.283 & 0.201 \\
Ecocentrism X Attention & -0.040 & -0.522 & 0.602 \\
Ecocentrism X Clarity & 0.212 & 2.375 & 0.019 \\
Ecocentrism X Regulation & -0.051 & -0.553 & 0.581 \\
Anthropocentrism X Attention & 0.133 & 1.828 & 0.069 \\
Anthropocentrism X Xlarity & -0.015 & -0.175 & 0.860 \\
Anthropocentrism X Regulation & -0.225 & -2.606 & 0.010 \\
& & & \\
& & &
\end{tabular}

$R^{2}=0.101$ for block $2 ; \mathrm{D} R^{2}=0.123$ for block $3 ; p=0.000$. 
Table 4. Regression analysis. Dependent variable: Behavior

\begin{tabular}{llrrl}
\hline Block & Model & Beta & \multicolumn{1}{l}{$\mathrm{t}$} & $p$ \\
\hline 1 & Gender & -0.037 & -0.505 & 0.614 \\
& Age & 0.163 & 2.265 & 0.025 \\
& Ecocentrism & 0.136 & 1.730 & 0.085 \\
& Anthropocentrism & -0.147 & -0.1833 & 0.068 \\
Gender & -0.017 & -0.299 & 0.819 \\
& Age & 0.136 & 1.865 & 0.064 \\
Ecocentrism & 0.157 & 1.859 & 0.065 \\
Anthropocentrism & -0.160 & -1.947 & 0.053 \\
Attention & -0.089 & -1.147 & 0.253 \\
Clarity & 0.106 & 1.309 & 0.192 \\
Regulation & 0.055 & 0.715 & 0.476 \\
Gender & -0.056 & -0.779 & 0.437 \\
Age & 0.136 & 1.919 & 0.057 \\
Ecocentrism & 0.084 & 0.937 & 0.350 \\
Anthropocentrism & -0.178 & 2.231 & 0.027 \\
Attention & -0.096 & -1.272 & 0.205 \\
Clarity & 0.122 & 1.564 & 0.120 \\
Regulation & 0.113 & 1.497 & 0.136 \\
Ecocentrism X Attention & -0.019 & -0.250 & 0.803 \\
Ecocentrism X Clarity & 0.86 & 2.073 & 0.040 \\
Ecocentrism X Regulation & -0.086 & -0.923 & 0.357 \\
Anthropocentrism X Attention & 0.073 & 1.002 & 0.318 \\
Anthropocentrism X Clarity & -0.143 & -1.685 & 0.094 \\
Anthropocentrism X Regulation & -0.161 & -1.855 & 0.065 \\
& & & \\
& & &
\end{tabular}

$R^{2}=0.102$ for block $2 ; \mathrm{D} R^{2}=0.110$ for block $3 ; p=0.001$.

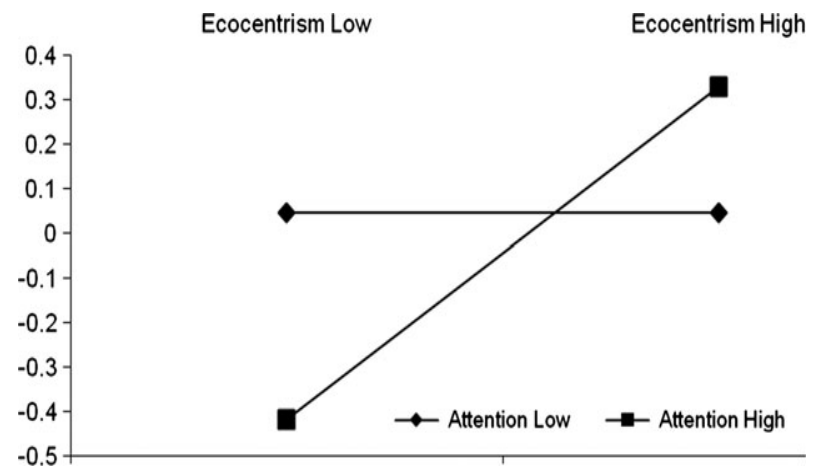

Fig. 1. Interaction between ecocentrism and emotional attention in pre- dicting attitude. 


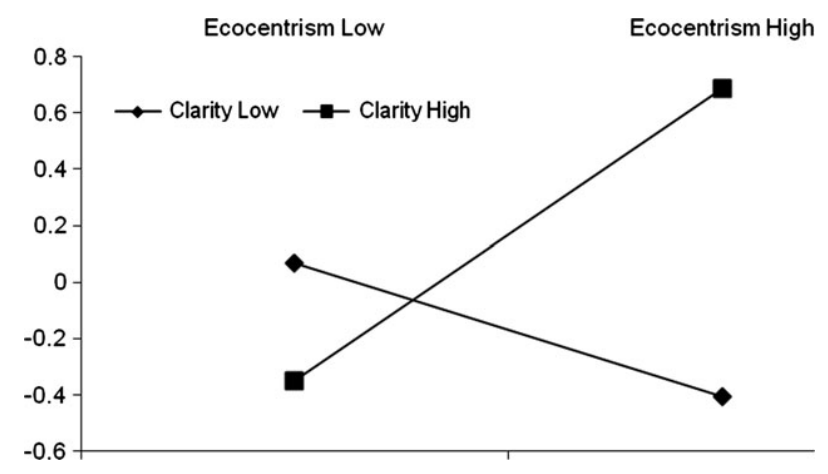

Fig. 2. Interaction between ecocentrism and emotional clarity in predict- ing intention.

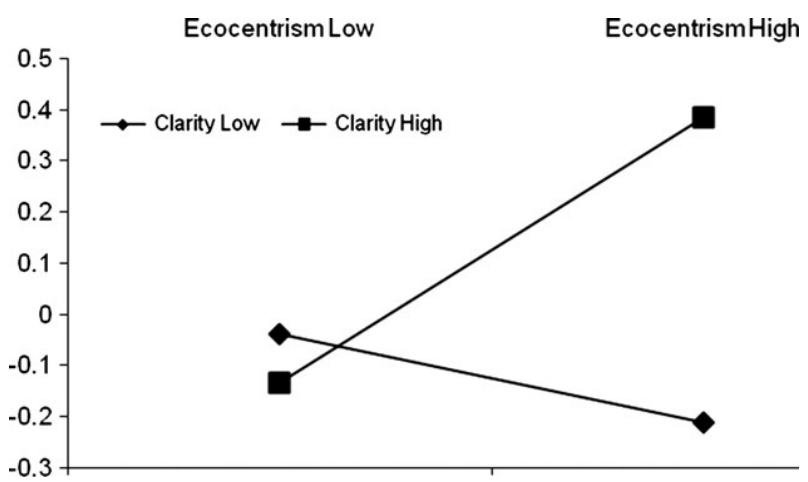

Fig. 3. Interaction between ecocentrism and emotional clarity in predict- ing behavior.

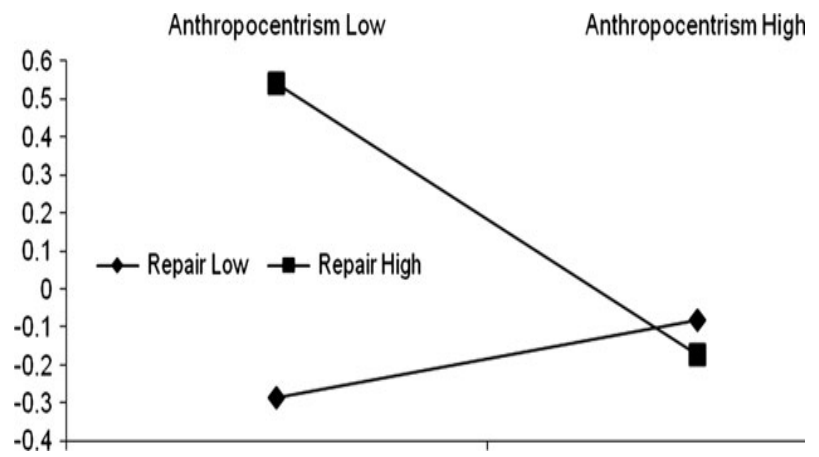

Fig. 4. Interaction between anthropocentrism and emotional repair in predicting attitude. 


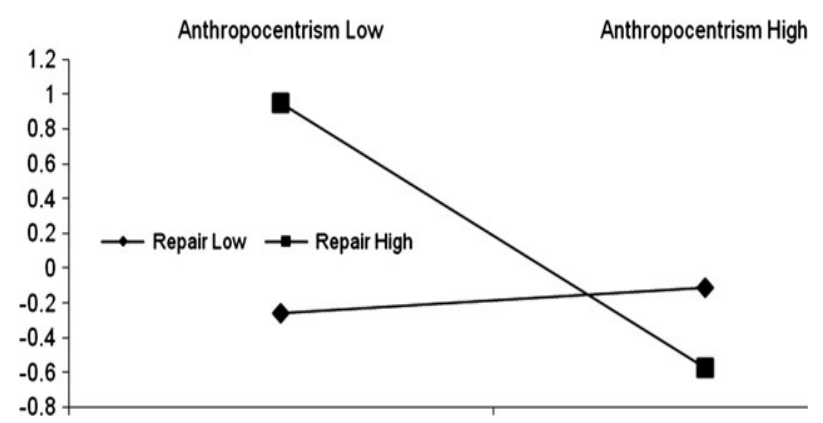

Fig. 5. Interaction between anthropocentrism and emotional repair in predicting intention.

\section{DISCUSSION AND CONCLUSIONS}

The objective of this study was to analyze the role of emotional intelligence as a moderating variable in the relationship between anthropocentric beliefs, ecocentric beliefs, and pro-environmental behavior. Two hypotheses were set. The first hypothesis in this study established that there were interaction effects between emotional intelligence and ecocentrism with regard to pro- environmental attitude, intention and behavior. More specifically, it established that respondents with stronger ecocentric beliefs and better abilities to manage their emotions, would have a more favorable attitude towards behavior (H.1.a), a greater intention to engage in the behavior (H.1.b) and more frequent engagement in pro-environmental behavior (H.1.c). This hypothesis has been confirmed. The results revealed that there were significant inter- action effects between ecocentrism and emotional attention in predicting attitude towards the behavior. They further showed that there were interaction effects between ecocentrism and emotional clarity in predicting behavioral intention and the frequency of recycling behavior.

Our findings revealed that our capacity to pay attention to and understand our emotions and likewise, our ability to regulate our emotional state or mood with respect to environmental beliefs, play an important role in creating behavioral dispositions. Authors such as Cabezas-Hernández (2009) or Trinidad and Johnson (2002), report that the capacity to recognize emotions is a key factor in identifying beliefs. Furthermore, if a person is able to regulate these emotions in an adaptive way, they will be able to anticipate the consequences of their actions. Since the model by Salovey and Mayer (1990) was proposed, emotions have been assigned a utilitarian function: it was considered that intelligent management of emotions facilitates information processing, by unifying 
emotions and reasoning, thereby making the latter more effective in behavior-related decision making (Grewal, Brackett \& Salovey, 2006; Mayer \& Salovey, 1997). The decision making process involved in determining whether an individual engages in a certain behavior or acts in a certain way, has been termed "behavioral intention" (Fishbein \& Ajzen, 1975; Gollwitzer, 1993; Triandis, 1977) and requires the implementation of a conscious plan for fulfillment (Eagly \& Chaiken, 1993). The plan will take into consideration the different alternatives and information available at the time - in our case, environmental beliefs.

The results revealed significant positive effects of the interaction between ecocentrism and emotional clarity, in the case of behavior. This suggests that people who place a higher value on Nature per se and who believe that human beings are a mere element forming part of Nature, show a high capacity to understand their own feelings and emotions and, at the same time, are also more likely to behave in a pro-environmental fashion. One possible explanation for these results might be that people who are aware of and understand their emotional reaction to a given situation, might also be more able to link their beliefs and attitudes to their emotions, thereby enabling them to make more accurate judgments about the perceived need for a particular behavior.

The second hypothesis raised in this study established that emotional intelligence may moderate the relationship between anthropocentric beliefs and attitude towards behavior (H.2.a), intention (H.2.b) and pro-environmental behavior (H.2.c). However, the interaction effects observed are not compatible with those predicted in the hypothesis. In hypothesis $2 \mathrm{a}$, it was established that interaction effects between stronger anthropocentric beliefs and high emotional regulation would create a less favorable attitude. But our results show that when there is a high level of anthropocentrism, there are no interaction effects with emotional regulation. Interaction effects occur when there is a low level of anthropocentric beliefs and greater emotional regulation.

Furthermore, hypothesis $2 \mathrm{~b}$ establishes that the interaction effects between a higher level of anthropocentric beliefs and high emotional regulation lead to less intention to engage in a particular behavior. However, the results indicate that when there is a high level of anthropocentrism, there are no interaction effects with emotional regulation. Interaction effects occur when there is a lower level of anthropocentric beliefs and greater emotional regulation. 
These results suggest that, to the extent that people do not consider themselves lords and masters of Nature, and are efficient in regulating their emotions, they are more likely to improve their pro-environmental attitudes and their intention to behave accordingly. This would lead us to conclude that emotional regulation may play an important role in predicting better pro-environmental attitudes in the case of people who do not hold anthropocentric beliefs.

When participants are able to regulate their emotions adaptively (i.e., when they have a good level of emotional repair) and the degree of anthropocentrism is low, we find more favor- able attitudes towards glass recycling. Thus, even when people think that human beings may be lords and masters of Nature, efficient management of emotions can still have an effect on attitudes towards glass recycling. According to Extremera and FernándezBerrocal (2004), emotional repair is closely related to recognizing the emotion evoked at the time, namely, emotional attention. Therefore, it is not surprising that attitudes should become more favorable or positive, to the extent that people are capable of experiencing, recognizing and regulating the emotions associated with feeling (or being) more proenvironmental (high degree of ecocentrism) or less anti-environmental (low degree of anthropocentrism). With regard to behavioral intention, our results show that there is an interaction between anthropocentrism and emotional repair. These results suggest that, as emo- tional repair increases and anthropocentrism decreases, the level of anthropocentrism is moderated by emotional repair and affects the intention to separate glass from other waste.

The results obtained show that, in the case of behavior, there are no interaction effects. Accordingly, there is no support for our Hypothesis 2c. Considering that anthropocentrism generally has a negative relationship with pro-environmental behavior (e.g., Amérigo \& González, 1999; González \& Amérigo, 1999; Vozmediano \& San Juan, 2005), these results are to be expected. In other words, according to our results, a person placing greater value on their natural environment and its contribution to the quality of human life will be less likely to engage in the behavior of separating glass from other waste.

The general pattern of results shows that when ecocentrism is high and at least one of the dimensions of emotional intelligence, (more specifically attention and clarity) is also high, it produces an attitude that is more favorable towards glass recycling, more inten- tion of behavior, and a higher frequency of behavior. These results partially support our hypothesis 
(H1). As previously argued, to establish this hypothesis, the moderating effects of emotional intelligence become evident only when people present a high attachment toward ecocentric beliefs and this is accompanied by a high ability to manage emotions according to these beliefs.

In contrast, the general pattern of results shows that when anthropomorphism and dimensions of emotional intelligence are high, we fail to observe a more favorable attitude, a higher intention, or a higher frequency of behavior. These results are some- what in accordance with the arguments of our hypothesis $(\mathrm{H} 2)$. In relation to anthropomorphic beliefs, we have found significant moderating effects (interaction effects) when these are low and some of the abilities of emotional intelligence, and in particular emotional repair, is high. Although our hypothesis 2 does not predict more favorable attitudes, a higher intention and a higher frequency of behavior when the anthropomorphic beliefs are high, the findings are again compatible with the arguments offered for this hypothesis. That is, if the anthropomorphic beliefs are low, they can result in people showing emotions that motivate a higher attitude of behavior and a higher frequency in behavior.

Nevertheless, a question to resolve from these results is why, for each of the dependent variables considered (attitude, intention and behavior), the moderating effects are only obtained for one of the three capacities of emotional intelligence that have been analyzed. We can offer at least two reasons for this finding.. One possibility is that the different abilities that constitute emotional intelligence that have been considered (attention, clarity and regulation) tend to be somehow related, so they can share explained variance. Thus, it is possible that, considering its effects, one of these abilities could be modulating the relation with a higher intensity. Another explanation comes from the fact that in the environment literature, myriad predicting variables of behavior have been identified. In our case, we need to take into account the fact that only beliefs towards the environment have been considered, and that these also tend to appear in different prediction models as a distal variable rather than a proximal variable, and it is therefore possible that the results could be due to an influence of these other variables that have not been considered in the present study (e.g., values, or perceived moral obligation).

Although the percentages of explained variance in the successive blocks of the regression analysis (for attitude towards behavior, intention and behavior) were not high, the results showed that these percentages increase when the dimensions of emotional intelligence are 
introduced, along with their interactions with anthropocentric and ecocentric beliefs. Accordingly, the results of this study show the important role played by emotional intelligence in studies on environmental behavior.

Finally, it could be suggested that the results obtained show that dimensions of emotional intelligence moderate the relationship between environment beliefs, attitudes, intentions and pro- environmental behaviors when ecocentrism is high and anthropomorphism is low.

By way of conclusion, the results suggest that the inclusion of emotional intelligence as a moderator variable in the relationship between beliefs, attitudes and environmental behavior could effectively help us to understand and enhance the models used for predicting environmental behavior. In our opinion, this is one of the major contributions of this study. However, we also feel that further research is required to help clarify the role played by the intelligent use of emotions in engaging in pro- environmental behavior. It might also be advisable for us to query whether our results really portray the new ecological intelligence described by Goleman (2009). The range of practical applications, in which the results of this study might be used, include a particularly important option, that is, teaching people to identify, manage and understand their emotions, as part of an activity program in environmental education in which training in emotional intelligence could foster the development of attitudes, intentions and behaviors aimed at protecting the environment. According to García-Mira, Arce and Sabucedo (1997), we need to redefine the current lines of action covered by so-called environmental education, to include specific programs aimed at developing and fostering emotionally intelligent personalities.

Finally, we would like to mention the possible limitations of this study. One of the possible limitations may be the fact that the sample used was made up entirely of undergraduate students; accordingly, we feel that the study should be repeated using a different type of sample. Another limitation is that we did not measure whether the emotions experienced by respondents when separating glass from other waste were more or less positive; this aspect should also be dealt with in a subsequent study. Some authors have reported that attitudinal ambivalence acts as a moderator on the relationship between attitudes and behavior (Armitage \& Conner, 2001; Ojala, 2008; Povey, Wellens \& Conner, 2001). We should therefore consider whether the optimal management of emotions, that is, emotional intelligence, acts as a facilitator or an inhibitor of ambivalent environmental attitudes. It is necessary that future research takes into account the other variables that have been identified 
in the literature concerning attitudes and environmental behavior, along with emotional intelligence.

\section{REFERENCES}

Abdullah, M., Elias, H., Mahyuddin, R. \& Uli, J. (2004). Emotional intelligence and academic achievement among Malaysian secondary students. Pakistan Journal of Psychological Research, 19, 105-121.

Aguilar-Luzón, M. C., García-Martínez, J. M. A., Calvo-Salguero, A. \& Salinas, J. M. (2012). Comparative study between the theory of Planned Behavior and the Value-Belief-Norm model regarding the environment, on Spanish housewives' recycling behavior. Journal of Social Applied Psychology, 42, 2797-2833.

Aiken, L. S. \& West, S. G. (1992). Multiple regression: Testing and interpreting interactions. Newbury Park, CA: Sage.

Ajzen, I. (1991). The theory of planned behavior. Organizational Behavior and Human Decision Process, 50, 179-211.

Amérigo, M. (2009). Concepciones del ser humano y la naturaleza desde el antropocentrismo y el biosferismo. Medio Ambiente y Comportamiento Humano, 10, 217-234.

Amérigo, M., Aragonés, J. I., De Frutos, B., Sevillano, V. \& Cortés, B. (2007). Underlying dimensión of ecocentric and anthropocentric enviromental beliefs. The Spanish Journal of Psychology, 10, 99-105.

Amérigo, M., Aragonés, J. I., Sevillano, V. \& Cortés, B. (2005). La estructura de las creencias sobre la problemática ambiental. Psicothema, 17, 246-251.

Amérigo, M. \& González, A. (1999). Actitudes hacia el medio ambiente y conducta ecológica. Psicothema, 11, 13-25.

Aragonés, J. I. (1990). Conservación de recursos naturales: Agua, suelos y energía. In R. De Castro, J. I. Aragonés \& J. A. Corraliza (Eds.), La conservación del entorno. Programas de intervención en Psicología Ambiental (pp. 69-89). Sevilla: Agencia del Medio Ambiente. Junta de Andalucía.

Aragonés, J. I. \& Amérigo, M. (1991). Un estudio empírico sobre las actitudes ambientales. Revista de Psicología Social, 6, 223-240.

Armitage, C. J. \& Conner, M. (2001). Efficacy of the theory of planned behaviour: a metaanalytic review. British Journal of Social Psychology, 40, 471-499. 
Augusto-Landa, J. M., López-Zafra, E., Berrios-Martos, M. P. \& Aguilar-Luzón, M. C. (2008). The relationship between emotional intelligence, occupational stress and health in nurses: A questionnaire survey. International Journal of Nursing Studies, 45, 888-901.

Bamberg, S. \& Møser, G. (2007). Twenty years after Hines, Hungerford, and Tomera: A new meta-analysis of psycho-social determinants of pro-environmental behavior. Journal of Environmental Psychology, 27, 14-25.

Baron, R. M. \& Kenny, D. A. (1986). The moderator-mediator variable distinction in social psychological research: Conceptual, strategic, and statistical considerations. Journal of Personality and Social Psychology, 51, 1173-1182.

Bar-On, R. (2000). Emotional and social intelligence: Insights from the Emotional Quotient Inventory. In R. Bar-On \& J. D. A. Parker (Eds.), The handbook of emotional intelligence (pp. 363-388). San Francisco, CA: Jossey-Bass.

Bechtel, R. B., Corral-Verdugo, V., Asai, M. \& González, A. (2006). A crosscultural study of environmental belief structures. USA, Japan, Mexico and Peru. International Journal of Psychology, 41, 145-151.

Bechtel, R., Corral-Verdugo, V. \& Pinheiro-Queiroz, J. (1999). Environ- mental belief systems. United States, Brazil and Mexico. Journal of Cross-cultural Psychology, 30, 122-128.

Belsley, D. A. (1982). Assessing the presence of harmful collinearity and other forms of weak data through a test for signal-to-noise. Journal of Econometric, 20, 211-253.

Belsley, D. A., Kuh, E. \& Welsch, R. E. (1980). Regression diagnostics: Identifying influential data and sources of collinearity. Hoboken, NJ: Wiley and Sons.

Berenguer, J. M. (2000). Actitudes y creencias ambientales. Una explicación psicosocial del comportamiento ecológico. Colección Tesis Doctorales. Cuenca: Servicios de Publicaciones de la UCLM.

Berenguer, J. M., Corraliza, J. A., Mart'in, R. \& Oceja, L. (2001). Pre- ocupación ecológica y acciones ambientales. Un proceso interactivo. Estudios de Psicolog'́a, 22, 37-52.

Bolzan de Campos, C. (2008). Sistemas de gestión ambiental y comportamiento proambiental de trabajadores fuera de la empresa: Aproximación de una muestra Brasilena. Tesis Doctoral: Universidad de Barcelona.

Bolzan de Campos, C. \& Pol, E. (2010). Can the environmental beliefs of workers from environmental certified companies predict their environmental behavior outside the organization? Estudos de Psicolog'ia (Natal), 15, 199-206.

Brackett, M. A. \& Salovey, P. (2006). Measuring emotional intelligence with the MayerSalovey-Caruso Emotional Intelligence Test (MS- CEIT). Psicothema, 18, 34-41. 
Bragg, E. A. (1996). Towards ecological self: Deep ecology meets constructionist self-theory. Journal of Environmental Psychology, 16, 93-108.

Cabezas-Hernández, M. M. (2009). Ética y emociones: De la inteligencia emocional a la educación moral. In P. Fernández-Berrocal (Ed.), Avances en el estudio de la inteligencia emocional (pp. 27-32). Fundación Marcelino Botín: Santander.

Carrus, G., Passafaro, P. \& Bonnes, M. (2008). Emotions, habits and rational choices in ecological behaviors: The case of recycling and use of public transportation. Journal of Environmental Psychology, 28, 51-62.

Ciarrochi, J., Forgas, J. \& Mayer, J. (2001). Emotional intelligence in everyday life: A scientific inquiry. Philadelphia, PA: Psychology Press.

Corraliza, J. A. \& Mart'1n, R. (2000). Estilos de vida, actitudes y comportamientos ambientales. Medio Ambiente y Comportamiento Humano: Revista Internacional de Psicolog'ı́a Ambiental, 1, 31-56.

Corraliza, J.A., Berenguer, J., Mu^noz, M. D. \& Martín, R. (1995). Perfil de creencias y actitudes ambientales de la población española. In E. Garrido \& C. Herrero (Eds.), Psicología política, jurídica y ambiental (pp. 327-336). Salamanca: Eudema.

Corral-Verdugo, V. \& Armendáriz, I. (2000). The New Enviromental Paradigm in a Mexican community. Journal of Environmental Education, 31, 25-31.

Dreger, R. M. \& Chandler, E. W. (1993). Confirmation of the construct validity and factor structure of the measure of anthropocentrism. Journal of Social Behavior and Personality, 8, 189-202.

Dunlap, R. E. (1991). Public (environmental) opinion in the 1980s: Clear consensus, ambiguous commitment. Environment, 33, 10-15.

Dunlap, R., Van Liere, K., Mertig, A. \& Jones, R. E. (2000). Measuring endorsement of the New Ecological Paradigm: A revised NEP scale. Journal of Social Issues, 56, 425-442.

Durán, M., Alzate, M., López, W. \& Sabucedo, J. M. (2007). Emociones y comportamiento proambiental. Revista Latinoamericana de Psico- log'́a, 39, 287-296.

Eagly, A. H. \& Chaiken, S. (1993). The Psychology of attitudes. Fort Worth, TX: Harcourt Brace Jovanovich.

Extremera, N. \& Fernández-Berrocal, P. (2004). La importancia de desarrollar la inteligencia emocional en el profesorado. Revista Ibero- americana de Educación, 33, 1-9.

Extremera, N. \& Fernández-Berrocal, P. (2005). Perceived emotional intelligence and life satisfaction: Predictive and Incremental validity using the Trait Meta-mood Scale. Personality and Individual Differences, 39, 937-948. 
Fernández-Berrocal, P., Extremera, N. \& Ramos, N. (2004). Validity and reliability of the Spanish modified version of the Trait Meta-Mood Scale. Psychological Reports, 94, $751-755$.

Fishbein, M. \& Ajzen, I. (1975). Beliefs, attitude, intention and behavior: An introduction to theory research. Reading, MA: Addison Wesley.

Frith, C. D. \& Singer, T. (2008). The role of social cognition in decision making. Philosophical Transactions of the Royal Society of London. Series B, Biological Sciences, 363, 38753886.

Fullam, A. (2002). Adult attachment, emotional intelligence, health and immunological responsiveness to stress. Unpublished doctoral dissertation, Rutgers University, Newark, NJ.

Furnham, A., Chamorro-Premuzic, T. \& Moutafi, J. (2005). Personality and intelligence: Gender, the big five, self-estimated and psychometric intelligence. International Journal of Selection and Assessment, 13, 11-24.

García-Mira, R., Arce, C. \& Sabucedo, J. M. (1997). Evaluación de la preferencia ambiental mediante escalamiento multidimensional. Revista de Psicolog'́a Social Aplicada, 7, 5375 .

Garc'ia-Mira, R. \& Real-Deus, E. (2001). Valores, actitudes y creencias, hacia un modelo predictivo del ambientalismo. Medio ambiente y Comportamiento Humano. Revista Internacional de Psicolog'́ 'a Ambi- ental, 2, 21-43.

García-Mira, R., Santos, M. C., Gómez-Durán, B., Romay, J. \& Fernández, M. A. (1998). Evaluación de las actitudes ambientales en trabajadores de grandes organizaciones. Revista de Psicolog'́a Social, 13, 435-444.

Goldenberg, I., Matheson, K. \& Mantler, J. (2006). The assessment of emotional intelligence: A comparison of performance-based and self- report methodologies. Journal of Personality Assessment, 86, 33-45.

Goleman, D. (1995). Emotional intelligence. New York: Bantam Books.

Goleman, D. (2009). Inteligencia ecológica. Buenos Aires: Editorial Vergara.

Gollwitzer, P. M. (1993). Goal achievement: The role of intentions. In W. Stroebe \& M. Hewstone (Eds.), European review of social psychology (Vol. 4, pp. 141-185). Chichester: Wiley. 
González, J.M. (2004). Las actitudes medioambientales de los espanoles en las encuestas de opinión pública. In M. Amérigo, B. Cortés, V. Sevillano \& F. Talayero (Eds.), Medio ambiente e interacción humana, avances en la investigación e intervención (pp. 135-139). Castilla La Mancha: Universidad de Castilla La Mancha.

González, A. \& Amérigo, M. (1999). Actitudes hacia el medio ambiente y conducta ecológica responsable. Psicothema, 11, 13-25.

Gooch, G. D. (1995). Environmental beliefs and attitudes in Sweden and the Baltic States. Environmental and Behavior, 27, 513-539.

Grob, A. (1995). A structural model or environmental attitudes and behavior. Journal of Environmental Psychology, 15, 209-220.

Hartig, T., Kaiser, F. G. \& Bowler, P. A. (2001). Psychological restora- tion in nature as a positive motivation for ecological behavior. Environment and Behavior, 33, 590-607.

Hawcroft, L. J. \& Milfont, T. L. (2010). The use (and abuse) of the new environmental paradigm scale over the last 30 years: A meta-analysis. Journal of Environmental Psychology, 30, 143-158.

Hinds, J. (2006). Affective connection and identification with the natural environment. In J. A Corraliza, J. Berenguer \& R. Mart'in (Eds.), Medio ambiente, bienestar humano y responsabilidad ecológica (pp. 311-315). Madrid: Resma.

Iniguez, L. (1994). Estrategias psicosociales para la gestión del agua: Del enfoque individualista al enfoque social. Simposium presentado en IV Congreso de Psicología Ambiental, 5-8 de Abril. Adeje: Tenerife.

Kals, E., Schumacher, D. \& Montada, L. (1999). Emotional affinity toward nature as a motivational basis to protect nature. Environment and Behavior, 31, 178-202.

Kim, Y. (2005). Emotional and cognitive consequences of adult attach- ment: The mediating effect of the self. Personality and Individual Differences, 39, 913-923.

Kokkarinen, N. \& Cotgrave, A.J. (2010). Built environment student attitudes toward the environment. In C. Egbu (Ed.), Procs 26th Annual ARCOM Conference, 6-8th September, Leeds, UK. Retrieved 5 Feb- ruary 2014 from http://www.arcom.ac.uk/docs/proceedings/ar2010-0173-0180_Kokkarinen_and_Cotgrave.pdf.

Lopes, P., Cotè, S. \& Salovey, P. (2007). Un modelo de habilidad de la inteligencia emocional: Implicaciones para la evaluación y el entrenamiento. In J.M. Mestre \& P. FernándezBerrocal (Eds.), Manual de inteligencia emocional (pp. 217-234). Madrid: Pirámide. 
Lumley, M. A., Gustavson, B. J., Partridge, R. T. \& Labouvie-Vief, G. (2005). Assessing alexithymia and related emotional ability constructs using multiple methods: Interrelationships among measures. Emotion, 5, 329-342.

Mayer, J. D. \& Salovey, P. (1997). What is emotional intelligence? In P. Sa- lovey \& D. Sluyter (Eds.), Emotional development and emotional intelligence: Implications for educators (pp. 3-31). New York: Basic Books.

Mayer, J. D. (2001). A field guide to emotional intelligence. In J. Ciarrochi, J. P. Forgas \& J. D. Mayer (2001). Emotional Intelligence in Everyday Life. Philadelphia, PA: Psychology Press.

Mayer, J. D., Salovey, P., Caruso, D. R. \& Sitarenios, G. (2001). Emotional intelligence as a standard intelligence. Emotion, 1, 232-242.

Ojala, M. (2008). Recycling and ambivalence: Quantitative and qualitative analyses of household recycling among young adults. Environment and Behavior, 40, 777-797.

Otto, J. \& Lanterman, E. (2006). Individual differences in emotional clarity and complex problem solving. Imagination, Cognition and Personality, 25, 3-24.

Palavecinos, M., Amérigo, M. \& Mu^noz, J. (2010). Preocupación y conducta ecológica responsable en estudiantes universitarios: El rol de la Universidad en la Educación Ambiental. Comunicación Presentada al Congreso Iberoamericano de Educación-METAS 2021. Buenos Aires: Argentina. Retrieved 20 January 2014 from http://www.chubut.edu. ar/descargas/secundaria/congreso/METAS2021/RLE2577_Palavecinos. pdf.

Pato, C., Ros, M. \& Tamayo, A. (2005). Creencias y comportamiento ecológico: Un estudio empírico en estudiantes. Medio Ambiente y Comportamiento Humano, 6, 5-22.

Pérez-González, J. C., Petrides, K. V. \& Furnham, A. (2005). La medida de la inteligencia emocional rasgo. In J. M. Mestre \& P. Fernández- Berrocal (Eds.), Manual de inteligencia emocional (pp. 81-97). Madrid: Pirámide.

Povey, R., Wellens, B. \& Conner, M. (2001). Attitudes towards follow- ing meat, vegetarian and vegan diets. An examination of the role of ambivalence. Appetite, 37, 15-26.

Roberts, R. D., Zeidner, M. \& Mathews, G. (2001). Does emotional intelligence meet traditional standards for an intelligence? Some new data and conclusions. Emotion, 1, 196-231.

Salovey, P. \& Mayer, J. (1990). Emotional intelligence. Imagination, Cognition and Personality, 9, 185-211. 
Salovey, P., Mayer, J., Goldman, S., Turvey, C. \& Palfai, T. (1995). Emotional attention, clarity and repair: Exploring emotional intelligence using the Trait Meta-Mood Scale. In J. W. Pennebaker (Ed.), Emotion, Disclosure and Health (pp. 125-154). Washington, DC: American Psychological Assessment.

Schmuck, P. \& Schultz, P. W. (2002). Sustainable development as a challenge for psychology. In P. Schmuck \& P. W. Schultz (Eds.), Psychology of Sustainable Development (pp. 317). Norwell, Massachusetts: Kluwer.

Schultz, P. W. (2000). Empathizing with nature: The effects of perspective taking on concern for environmental issues. Journal of Social Issues, 56, 391-406.

Schultz, P. W. (2001). The structure of environmental concern: Concern for self, other people, and the biosphere. Journal of Environmental Psychology, 21, 327-339.

Schultz, P. W., Shriver, C., Tabanico, J. J. \& Khazian, A. M. (2004). Implicit connections with nature. Journal of Environmental Psychology, 24, 31-42.

Scott, D. \& Willits, F. K. (1994). Environmental attitudes and behavior: A Pennsylvania Survey. Environment and Behavior, 26, 239-260.

Snelgar, R. S. (2006). Egoistic, altruistic, and biospheric environmental concerns: Measurement and structure. Journal of Environmental Psychology, 26, 87-99.

Stern, P. C. (1992). Psychological dimensions of global environmental change. Annual Review of Psychology, 43, 269-302.

Stets, J. E. \& Biga, C. F. (2003). Bringing identity theory into environ- mental sociology. Sociological Theory, 21, 398-423.

Syme, G. J., Beven, C. E. \& Sumner, N. R. (1993). Motivation for reported involvement in local wetland preservation: The roles of knowledge, disposition, problem assessment, and arousal. Environment and behavior, 25, 586-606.

Triandis, H. C. (1977). Interpersonal behavior. Monterrey, CA: Brooks- Cole.

Trinidad, D. R. \& Johnson, C. A. (2002). The association between emotional intelligence and early adolescent tobacco and alcohol use. Personality and Individual Differences, 32, 95-105.

Tsaousis, I. \& Nikolaou, I. (2005). Exploring the relationship of emotional intelligence with physical and psychological health functioning. Stress and Health, 21, 77-86.

Vozmediano, L. \& San Juan, C. (2005). Escala Nuevo Paradigma ecológico: Propiedades psicométricas con una muestra espanola obtenida a través de Internet. Medio Ambiente y Comportamiento Humano, 6, 37-49.

Received 18 March 2014, accepted 27 July 2014 